\title{
Aktualisasi Peran Pegadaian Dalam Pengembangan Usaha Menurut Perspektif Bisnis Syariah \\ (Studi Kasus pada Usaha Pedagang Kaki Lima di Watampone)
}

\author{
Agusandi Pratama \\ Stain Watampone \\ AgusandiPratama@gmail.com
}

\begin{abstract}
This research discusses the actualization of the role of pawnshops in business development according to the Islamic business perspective. This research is conducted to measure how much the role of pawnshops in developing street vendors in Watampone is used by sellers in trading. Looking at the work of the majority of street vendors, the majority of entrants, therefore researchers are interested in discussing the budget costs incurred in developing the business. This study aims to determine the role of pawnshops in developing street vendors in Watampone. Based on the objectives of the above research, the type of research used is field research using a qualitative approach. This study uses the method of observation, interviews, and documentation in collecting the required data. The collected data is then processed using Descriptive Analysis techniques and interactive analysis models. The results of the analysis show that the role of pawnshops has a significant effect in developing a street vendor business in Watampone. The magnitude of the influence of the role of pawnshops on street vendors continues to increase for 10 years. The result can be used as a reference to find out the influence of the role of pawnshops on street vendors in Watampone.
\end{abstract}

Keywords: Role of pawnshops, Business Development, Sharia Business

\begin{abstract}
Abstrak
Peneilitian ini membahas tentang aktualisasi peran pegadaian dalam pengembangan usaha menurut perspektif bisnis syariah. Penelitian ini dilaksakan untuk mengukur berapa besar peran pegadaian dalam mengembangkan pedagang kaki lima di Watampone yang digunakan oleh para penjual dalam berdagang. Melihat dari pekerjaan sebagian besar pedagang kaki lima mayoritas pendatang, maka dari itu peneliti tertarik untuk membahas tentang anggaran biaya yang dikeluarkan dalam mengembangan usaha. Penelitian ini bertujuan untuk mengetahui peran pegadaian dalam mengembangkan pedagang kaki lima di Watampone.Berdasarkan tujuan penelitian di atas, maka jenis penelitian yang digunakan adalah penelitian lapangan dengan menggunakan pendekatan kualitatif. Penelitian ini menggunakan metode observasi, wawancara, dan dokumentasi dalam mengumpulkan data yang diperlukan. Data yang telah terkumpul kemudian diolah dengan menggunakan teknik Descriptive
\end{abstract}

Jurnal Ilmiah Al Tsarwah

83

Program Magister Program Studi Ekonomi Syariah

Institut Agama Islam Negeri (IAIN) Bone 
Analysis dan model analisis interaktif. Hasil analisis menunjukkan bahwa peran pegadaian berpengaruh signifikan dalam mengembangkan usaha pedagabg kaki lima di Watampone. Besarnya pengaruh peran pegadaian terhadap pedagang kaki lima terus meningkat selama 10 tahun. Hasilnya ini dapat dijadikan sebagai acuan untuk mengetahui pengaruh peran pegadaian terhadap pedagang kaki lima di Watampone.

Kata kunci : Peran pegadaian, Pengembangan Usaha, Bisnis Syariah

\section{PENDAHULUAN}

Pedagang Kaki Lima (PKL) merupakan kelompok masyarakat yang memiliki keadaan ekonomi lemah, yang berjualan barang kebutuhan sehari- hari, makanan atau jasa dengan modal yang relatif kecil, modal sendiri atau modal orang lain. Pedagang kaki lima (PKL) dipandang sebagai patologi sosial karena memiliki ciri-ciri seperti ketidak-pastian, mobilitas, ketidakmampuan, serta kemiskinan dan tingkat pendidikan rendah. ${ }^{1}$

Dalam pengertian ini pedagang kaki lima sering dilekasi oleh ciri ciri perputaran uang kecil, tempat usaha yang tidak tetap, modal terbatas, segmen pasar pada masyarakat kelas menengah ke bawah dan jangkauan usaha yang tidak terlalu luas. ${ }^{2}$ Pada umumnya, pedagang kaki lima (PKL) menjalankan berbagai macam dagangan, mulai dari jajanan pasar, kuliner (makanan), barang-barang bekas seperti sepatu, perkakas, dan barang-barang yang dibutuhkan oleh masyarakat.

Pedagang Kaki Lima (PKL) merupakan salah satu usaha mikro di Watampone yang menjadi pilihan masyarakat untuk menjalankan usaha dagang. Namun dalam proses menjalankan usaha ini, para pedagang kaki lima (PKL) di Watampone sebagian besar masih mengalami kesulitan dalam hal permodalan sehingga sebagian besar pedagang kaki lima $(\mathrm{PKL})$ harus meminta atau mendapatkan bantuan pembiayaan dari lembaga keuangan syariah melalui usaha pembiayaan mikro syariah.Berkembangnya usaha

\footnotetext{
${ }^{1}$ Achsan, Ali Mustafa, Transformasi Sosial Masyarakat Marginal. (Malang: INSPIRE, 2008), h. 5.

${ }^{2}$ Ray Bromly, Organisasi, Peraturan dan Pengusahaan Sektor Informal Di Kota dalam Urbanisasi, Pengangguran dan Sektor Informal di Kota, Chris ManningTajudin Noer Efendi, (Jakarta: Yayasan Obor Indonesia,2007), h. 229.
} 
mikro, khususnya usaha pedagang kaki lima $(\mathrm{PKL})$ merupakan peran dari Pegadaian melalui produk pembiayaan mikro. ${ }^{3}$

Pegadaian merupakan salah satu lembaga keuangan di Kabupaten Bone yang membantu dalam mengembangkan usaha mikro melalui produk pembiayaan melalui produk pembiayaan mikro ini, pegadaian diharapkan mampu menanggulangi masalah permodalan yang dialami oleh para pelaku usaha mikro. ${ }^{4}$ Khusus para pedagang kaki lima (PKL), sehingga para pedagang kaki lima (PKL) dapat lebih mengembangkan usahanya.

Dalam hal ini, langkah dari Pegadaian telah memberikan semangat dan dorongan terhadap terbangunnya semangat para masyarakat Watampone yang berasal dari kalangan bawah yang ingin mencoba ikut serta dalam upaya mewujudkan perekonomian di daerah Watampone. Itu semua telah diwujudkan dengan upaya pengembangan usaha mikro yang benar-benar mengembangkan potensi ekonomi yang ada dalam kalangan masyarakat kabupaten Bone.

Jika dilihat pada data jumalh pedagang kali lima, dilihat pada tabel berikut: 5

Tabel 1.1

Pedagang Kaki Lima

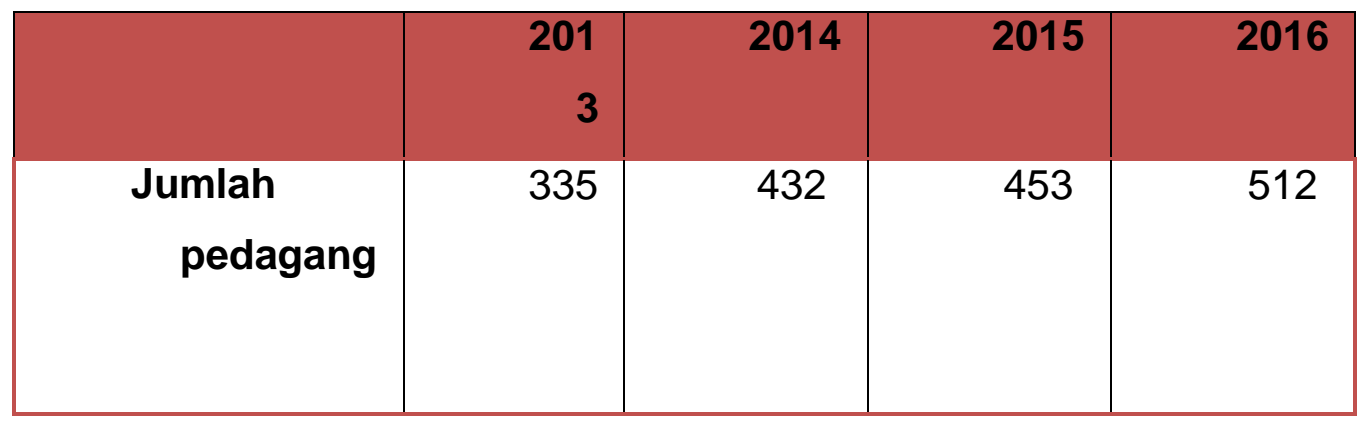

Berdasarkan tabel, dapat dilihat bahwa jumlah pedagang kaki lima (PKL) yang mengambil pembiayaan mengalami peningkatan dari tahun ketahun, yang menunjukkan bahwa pembiayaan mikro syariah diminati oleh pedagang kaki lima dan dianggap membantu permodalan. Dalam hal ini, langkah dari Pegadaian Syariah telah

${ }^{3}$ Wawancara pribadi dengan Bapak Fauzan, Teller KCPWatampone, 12 juli 2017. 2006), h. 15.

${ }^{4}$ Antonius Alijoyo, Baik Perbankan Maupun Sektor Rill Perlu Manajemen Resiko, (Jakarta: Sharing,

${ }^{5}$ Wawancara pribadi dengan Bapak Muhammad Fauzan, Account Officer Mikro Pegadaian Syariah KCP Watampone, 1 November 2017.

Jurnal Ilmiah Al Tsarwah 
memberikan semangat dan dorongan terhadap terbangunnya semangat masyarakat Watampone dari kalangan bawah yang ingin mencoba ikut serta dalam upaya mewujudkan perekonomian di daerah Watampone. Itu semua telah diwujudkan dengan upaya pengembangan usaha mikro yang benar-benar mengembangkan potensi ekonomi yang ada dalam kalangan masyarakat kabupaten Bone. Dengan demikian, Pegadaian Syariah Watampone dianggap memiliki peran dalam mengembangkan usaha para pedagang kaki lima (PKL) yang mengambil pembiayaan mikro di Pegadaian Syariah terutama dalam masalah permodalan agar dapat lebih meningkatkan potensi dalam bidang usaha yang dijalankan para pedagang kakilima (PKL).

Berdasarkan uraian tersebut, penulis perlu untuk meneliti serta mengkaji lebih jauh tentang bagaimana aktualisasi bantuan dana Pegadaian Watampone dalam mengembangkan usaha pembiayaan mikro karena penelitian ini ingin membuktikan apakah pegadaian berperan dalam pengembangan usaha. Namun, pada hal ini peneliti lebih berfokus pada Pedagang kaki lima (PKL) yang mengambil pembiayaan mikro di Pegadaian yang ada di Watampone.

Berdasar pada uraian-uraian yang telah dipaparkan, maka permasalahan pokok yang dijadikan obyek bahasan Apa yang dimaksud pembiayaan mikro kreasi di Pegadaian dan Apa peran aktual Pegadaian dalam mengembangkan usaha pedagang kaki lima (PKL) di Watampone?

\section{B. TINJAUAN PUSTAKA}

Dalam melakukan penelitian tentu saja harus bisa menunjukkan perbedaan antara penelitian yang akan dilakukan dengan penelitian yang sebelumnya telah dilakukan. Oleh karenanya tinjauan terkait penelitian sebelumnya yang memiliki kesamaan baik dari segi objek maupun variabel perlu dilakukan untuk menunjukkan bahwa penelitian yang akan dilakukan bukan tindakan plagiat.

Adapun penelitian terdahulu yang ditemukan adalah sebagai berikut: 
1. Penelitian yang dilakukan oleh, Syahruddin Kadir pada tahun 2014 melalui kajiannya yang berjudul "Pembiayaan Modal Kerja Lembaga Keuangan Mikro Syariah (Analisis Profitabilitas BMT As'adiyah Sengkang)". Inti kajiannya adalah jenis- jenis pembiayaan modal kerja serta profitabilitas pembiayaan modal kerja kategori lancar, kurang lancar, diragukan dan macet di BMT As'adiyah Sengkang pada tahun 2011- 2013. Metode pengumpulan data yang digunakan adalah metode library research dan metode field research.Teknik yang digunakan dalam penelitian ini adalah teknik kutipan (kutipan langsung dan kutipan tidak langsung). Sedangkan teknik analisis data yang digunakan adalah teknik analisis deskriptif dengan model analisis interaktif.Dalam penelitian ini analisis deskriptif digunakan untuk menggambarkan hasil observasi, dokumentasi dan wawancara dari para informan BMT As'adiyah sengkang tentang pembiayaan modal kerja lembaga keuangan mikro Syariah. Hasil penelitiannya menunjukkan bahwa profitabilitas BMT As'adiyah Sengkang menunjukkan pendapatan pembiayaan modal kerja meningkat dalam 3 tahun terakhir dan memberikan sumbangsih yang besar kepada BMT As'adiyah sengkang dibandingkan dengan pembiayaan lainnya (pembiayaan non modal kerja). Profitabilitas pembiayaan modal kerja kategori lancer BMT As' adiyah Sengkang menunjukkan adanya kemampuan yang besar dan efektivitas semakin baik mengelolah pembiayaan modal kerja dalam memperoleh kembali pokok pembiayaan dan pendapatannya. ${ }^{6}$

2. Penelitian yang dilakukan oleh, Fitriani pada tahun 2014 melalui kajiannya yang berjudul " pengaruh minat pedagang kaki lima terhadap pengambilan kredit pada koperasi mattiro deceng di Watampone". Inti kajiannya adalah minat pedagang kaki lima mengambil kredit di koperasi mattiro deceng berpengaruh signifikan pada faktor layanan, promosi, lokasi dan faktor ekonomi. Mengungkapkan penelitian tersebut bahwa, kehadiran koperasi sangat membantu pengusaha kecil seperti pedagang kaki lima karena sebagian dari mereka mempunyai masalah yang sama yaitu kurangnya modal yang dimiliki untuk mengembangkan usahanya. Melihat perkembangan di pasar

\footnotetext{
${ }^{6}$ Syahruddin Kadir, "Pembiayaan Modal Kerja Lembaga Keuangan Mikro Syariah (Analisis Profitabilitas BMT As'adiyah Sengkang)" Hasil Penelitian Individual Mahasiswa, Sekolah Tinggi Agama Islam Negeri (STAIN) Watampone, 2014.
}

Jurnal Ilmiah Al Tsarwah

Program Magister Program Studi Ekonomi Syariah

Institut Agama Islam Negeri (IAIN) Bone 
membuat sebagian pedagang kaki lima mengambil jalan pintas yaitu mengambil kredit di koperasi dan salah satunya koperasi yang banyak diminati pedagang kaki lima adalah koperasi mattiro deceng.

Data penelitian ini meliputi data primer dan sekunder. Data primer merupakan data utama penelitian ini.Sedangkan data sekunder digunakan sebagai pendukung data primer. Data dikumpulkan dengan teknik observasi. Hasil penelitiannya menunjukkan bahwa kehadiran koperasi sangat membantu pengusaha kecil seperti pedagang kaki lima karena sebagian pedagang kaki lima mempunyai masalah yang sama yaitu kurangnya modal yang dimiliki untuk mengembangkan usahanya. ${ }^{7}$

3. Penelitian yang dilakukan oleh Farida Ayu Avisena Nusantari Tahun 2011 dengan judul "peran BRI Syariah dalam meningkatkan pembiayaan mikro". Penelitian ini membahas tentang bagaimana peran BRI Syariah dalam peningkatan pembiayaan mikro. ${ }^{8}$

Dalam penelusuran terhadap beberapa hasil penelitian terdahulu, dapat ditemukan perbedaan dengan penelitian yang akan dilakukan pada penelitian ini. Dalam penelitian yang dilakukan oleh Syahruddin Kadir, penelitian ini mengkaji dan menjawab permasalahan mengenai pembiayaan modal kerja serta profitabilitas pembiayaan modal kerja kategori lancar, kurang lancar, diragukan dan macet di BMT As'adiyah Sengkang pada tahun 2011- 2013. Kemudian, profitabilitas BMT As'adiyah Sengkang menunjukkan pendapatan pembiayaan modal kerja meningkat dalam 3 tahun terakhir dan memberikan sumbangsih yang besar kepada BMT As'adiyah Sengkang dibandingkan dengan pembiayaan lainnya (pembiayaan non modal kerja). Penelitian yang dilakukan oleh Fitriani, penelitian ini bertujuan untuk mengetahui dan memberikan gambaran tentang apakah koperasi mattiro deceng berpengaruh signifikan pada faktor layanan, promosi, lokasi dan faktor ekonomi. Kemudian penelitian yang di lakukan oleh

${ }^{7}$ Fitriani, "Pengaruh Minat Pedagang Kaki Lima Terhadap Pengambilan Kredit Pada Koperasi Mattiro Deceng Di Watampone" Hasil Penelitian Individual Mahasiswi, Sekolah Tinggi Agama Islam Negeri (STAIN) Watampone, 2014, h.

${ }^{8}$ Farida Ayu Avisena Nusantari, Peran BRI Syariah dalam Meningkatkan Pembiayaan Mikro, Jakarta, 2011, h. 60-63. 
Farida Ayu Avisena Nusantari, penelitian ini bertujuan untuk mengetahui tentang apakah BRI Syariah berperan pada pembiayaan mikro.

Berdasarkan penelitian terdahulu diatas dapat memberi pemahaman bahwa penelitian yang akan dilakukan berbeda dengan penelitian yang dilakukan oleh Syahruddin Kadir, Fitriani danFarida Ayu Avisena Nusantari karena penelitian ini selain fokus pada aktualisasi peran pegadaian juga fokus pada prinsip Bisnis Syariah

\section{KERANGKA PIKIR}

Berdasarkan uraian yang telah dikemukakan sebelumnya, maka pada bagian ini diuraikan kerangka berpikir yang dijadikan landasan berpikir dalam melaksanaan penelitian. Adapun kerangka pikir yang dimaksud, adalah sebagai berikut:

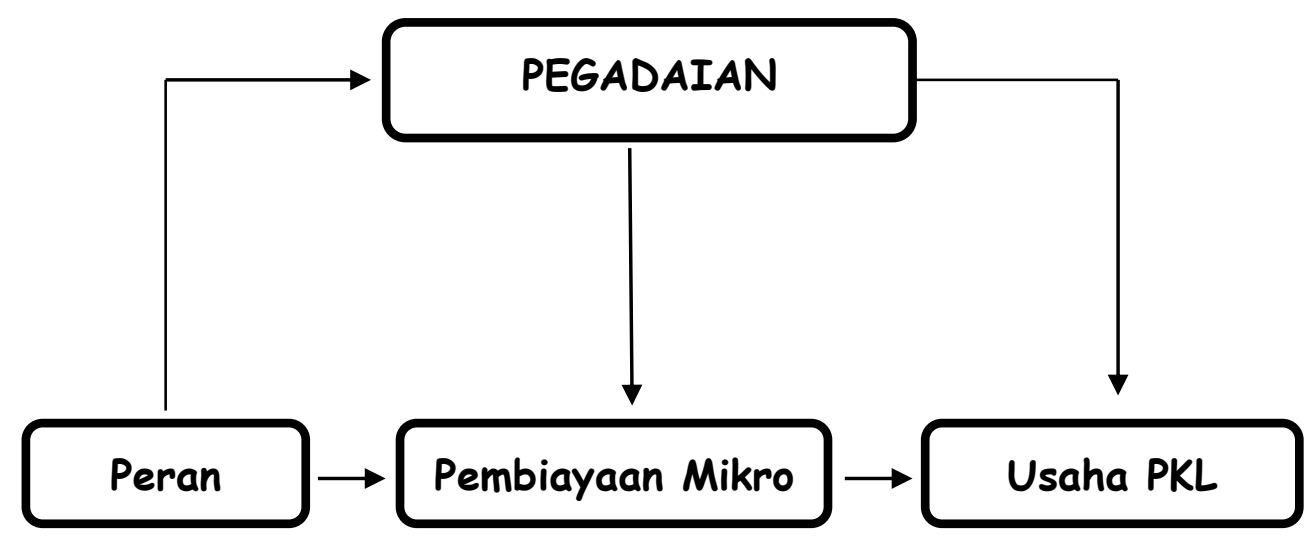

Berdasarkan kerangka pikir diatas dinyatakan bahwa pegadaian mengarah kepada perandalam pembiayaan mikro terhadap pengembangan usaha pedagang kaki lima dan juga berfokus pada pengungkapan aktualisasi pegadaian dalam pengembangan usaha pkl.

\section{G. METODE PENELITIAN}

\section{Jenis Penelitian}

Jenis penelitian yang digunakan pada penelitian ini adalah penelitian kualitatif, karena data yang disajikan dalam bentuk kata-kata bukan angka. Karena itu 
deskripsinya membutuhkan penafsiran (interpretasi) untuk mengetahui makna di balik kata.

\section{Pendekatan Penelitian}

Penelitian ini adalah penelitian lapangan dengan menggunakan pendekatan kualitatif. Sedangkan, desain penelitian yang digunakan adalah desain deskriptif kualitatif. Menurut Aaker desain penelitian adalah perencanaan terinci yang digunakan sebagai pedoman studi penelitian yang mengarah pada tujuan dari penelitian tersebut. ${ }^{9}$

Sedangkan tujuan desain penelitian deskriptif kualitatif adalah untuk menggambarkan, meringkaskan berbagai kondisi, fenomena realitas sosial yang ada di masyarakat yang menjadi obyek penelitian, dan berupaya menarik realitas itu ke permukaan sebagai suatu ciri, karakter, sifat, model, tanda, atau gambaran tentang kondisi, situasi, ataupun fenomena tertentu. ${ }^{10}$

Berdasarkan penjelasan tersebut di atas, maka dalam penelitian yang dilakukan ini, desain deskriptif kualitatif digunakan untuk menggambarkan bagaimana peran pegadaian dalam mengembangkan usaha pembiayaan mikro, khususnya pada usaha pedagang kaki lima yang ada di Watampone.

\section{Data dan Sumber Data}

Pengumpulan data dilakukan untuk memperoleh informasi yang dibutuhkan dalam rangka mencapai tujuan penelitian. Dalam hal ini, jenis data yang digunakan pada penelitian ini, yaitu:

a. Data Primer

${ }^{9}$ D.A. Aaker, V. Kumar Dan G.S. Day, Marketing Research (Hawkin: Mac. Millan Publishing Company, 2001), h.. 24.

${ }^{10}$ Burhan Mungim, Peneltian Kualitatif: Komunikasi, Ekonomi, Kebijakan Publik, Dan Ilmu Sosial Lainnya (Jakarta: Prenada Media Group, 2008), h. 68.

Jurnal Ilmiah Al Tsarwah

Program Magister Program Studi Ekonomi Syariah

Institut Agama Islam Negeri (IAIN) Bone 
Data primer merupakan data yang didapat dari sumber pertama dari individu. ${ }^{11}$ Data primer yang digunakan dalam penelitian ini, diperoleh secara langsung dari obyek/subyek penelitian.

b. Data Sekunder

Data sekunder adalah jenis data yang diperoeh dan digali melalui hasil penelitian lapangannya, baik berupa data kualitatif maupun data kuantitatif jenis data ini juga disebut dengan data eksternal. ${ }^{12}$

Data sekunder yang digunakan dalam penelitian ini, yaitu: dokumentasi dari pegadaian cabang Watampone, laporan-laporan yang sejenis, dan buku-buku literatur lainnya yang menunjang penelitian ini.

4. Teknik Pengumpulan data

Sedangkan teknik yang digunakan untuk mengumpulkan data-data tersebut di atas, yaitu:

\section{a. Observasi (Pengamatan)}

Observasi adalah instrumen pengumpulan data dengan cara mengamati obyek yang diteliti, yang didukung dengan pengumpulan dan pencatatan data secara sistematis. ${ }^{13}$ Teknik observasi dalam penelitianini digunakan untuk menghimpun berbagai macam keterangan (data) yang dilakukan dengan cara melakukan pencatatan secara sistematis mengenai kondisi pegadaian cabang Watampone dalam memberikan kredit kepada pihak nasabah.

b. Interview (Wawancara)

Wawancara adalah percakapan dengan maksud tertentu. Percakapan itu dilakukan oleh dua pihak, yaitu pewawancara (interviewer)yang mengajukan

\footnotetext{
${ }^{11}$ Husain Umar, Reseach Methods In Finance And Banking (Cetakan. 2; Jakarta: Gramedia Pustaka Utama, 2002), h. 82.

${ }^{12}$ Muhammad Teguh, Metodologi Penelitian Ekonomi: Teori dan Aplikasi, (Ed. 1: Cetakan. 3; Jakarta: RajaGrafindo Persada, 2005), h.118.

${ }^{13}$ S. Nasution, Metodologi Research Penelitian Ilmiah (Jakarta: Bumi Aksara, 2000), h. 10. 
pertanyaan dan terwawancara (interviewee) yang memberikan jawaban atas

pertayaan. ${ }^{14}$

c. Dokumentasi

Dokumentasi adalah teknik yang digunakan untuk mendapatkan data melalui prasasti, naskah-naskah kearsipan (baik dalam bentuk barang cetakan maupun rekaman), data gambar/foto/blue print dan lain sebagainya. ${ }^{15}$ Dalam penelitian ini, dokumentasi digunakan untuk memperoleh data tentang kondisi pegadaian dalam memberikan kredit usaha.

\section{Teknik Analisis Data}

Untuk menganalisis datayang telah dikumpulkan, maka teknik analisis data yang digunakan adalah teknik DescriptiveAnalysis dengan model analisis interaktif.

Teknik Descriptive Analysis dengan model analisis interaktif bertujuan untuk menggambarkan, meringkaskan berbagai kondisi, situasi, atau fenomena realitas sosial yang ada di masyarakat yang menjadi obyek penelitian, dan berupaya menarik realitas itu ke permukaan sebagai suatu ciri, karakter, sifat, model, tanda, atau gambaran tentang kondisi, situasi, ataupun fenomena tertentu.

\section{H. HASIL PENEILITIAN DAN PEMBAHASAN}

\footnotetext{
${ }^{14}$ Lexy J. Moleong, Metodologi Penelitian Kualitatif, Ed. Revisi (Cetakan. 22; Bandung: PT Remaja Rosdakarya, 2004), h. 189.

${ }^{15}$ Supardi, Metodologi Penelitian Ekonomi \& Bisnis (Cet. 1; Yogyakarta: UII Press, 2005), h. 138.

Jurnal Ilmiah Al Tsarwah

Program Magister Program Studi Ekonomi Syariah

Institut Agama Islam Negeri (IAIN) Bone
} 


\section{A. Deskripsi pembiayaan kreasi bagi pedagang kaki lima di Watampone}

Kreasi adalah kredit dengan angsuran bulanan yang diberikan kepada usaha kecil dan menengah (UKM) untuk pengembangan usaha dengan sistem fidusia.Sistem fidusia berarti agunan untuk pinjaman cukup dengan BPKB sehingga kendaraan masih digunakan nasabah. Kreasi merupakan solusi terpercaya untuk mendapatkan fasilitas kredit yang cepat,mudah dan murah. Layanan ini, tentunya sangat membantu pelaku UMKM. Saat ini, pemberian kredit dengan sistem fidusia sudah diatur dengan UU Nomor 42 Tahun 1999. Jangka waktu pinjaman dapat dipilih mulai 12 sampai 36 bulan. Bunga pinjaman pun relatif murah sekitar $1 \%$ perbulan. Pinjaman yang diberikan maksimal $70 \%$ dari nilai kendaraan dengan mempertimbangkan kemampuan bayar maksimal 2/3 dari rata-rata laba usaha perbulan.Kini, penyaluran kredit UMKM telah berkembang, tidak hanya dengan jaminan BPKB saja. Bagi para pedagang yang tak memiliki kendaraan bermotor, tetapi memiliki hak pemakaian kios pasar, dapat menikmati layanan kredit dengan jaminan SHPTU (Sertifikat Hak Pemakaian Tempat Usaha). Dengan jaminan ini, jangka waktu pinjaman bisa sampai 7 tahun.

Terkait banyaknya gerai gadai BPKB di masyarakat, tidak memengaruhi pertumbuhan produk KREASI. Tahun 2014, PT Pegadaian (Persero) berhasil menjaring 41.572 nasabah. Terhitung sampai 30 November 2015, jumlah nasabah produk ini meningkat menjadi 56.431 orang.Pada 2014, total penyaluran kredit mencapai Rp 729 milian. Sampai 30 November 2015, omset melesat menjadi Rp 1,14 triliun.

Jika dilihat pada data penyaluran pembiayaan Mikro pada Pegadaian Syariah Watampone, dilihat pada tabel berikut: ${ }^{16}$

\section{Tabel 3.1}

\section{Nasabah Pegadaian Syariah ( Kreasi )}

\begin{tabular}{|l|l|l|l|l|}
\hline & 2013 & 2014 & 2015 & 2016 \\
\hline
\end{tabular}

${ }^{16}$ Wawancara pribadi dengan Bapak Muhammad Fauzan, Account Officer Mikro Pegadaian Syariah KCP Watampone, 25 maret 2018. 


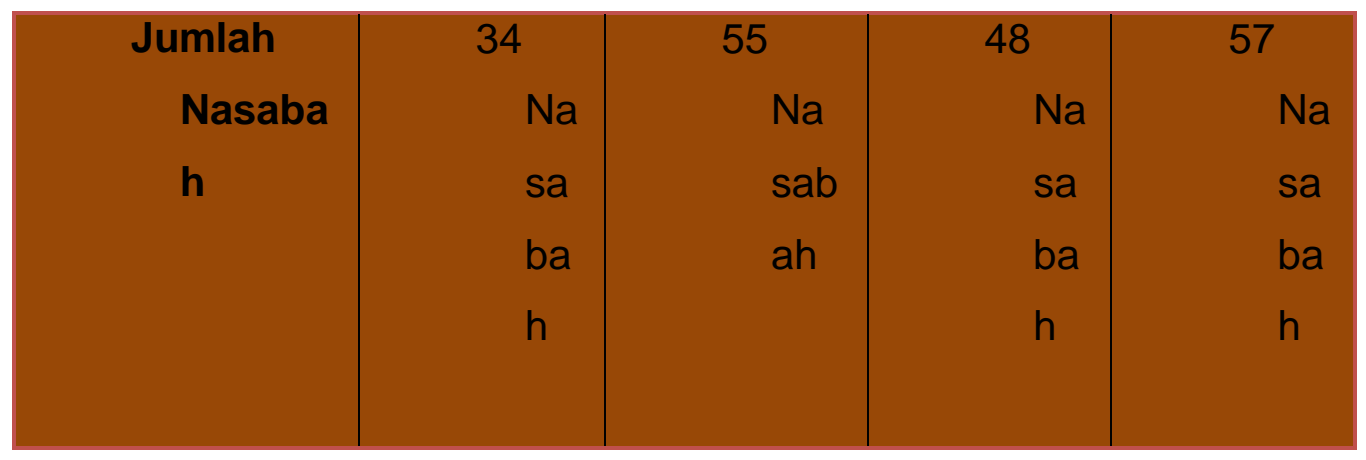

Berdasarkan tabel, dapat dilihat bahwa jumlah pedagang kaki lima (PKL) yang mengambil pembiayaan mikro di Pegadaian Syariah mengalami peningkatan dari tahun ketahun, yang menunjukkan bahwa pembiayaan mikro syariah diminati oleh pedagang kaki lima dan dianggap membantu permodalan. Dalam hal ini, langkah dari Pegadaian Syariah telah memberikan semangat dan dorongan terhadap terbangunnya semangat masyarakat Watampone dari kalangan bawah yang ingin mencoba ikut serta dalam upaya mewujudkan perekonomian di daerah Watampone. Itu semua telah diwujudkan dengan upaya pengembangan usaha mikro yang benar-benar mengembangkan potensi ekonomi yang ada dalam kalangan masyarakat kabupaten Bone. Dengan demikian, Pegadaian Syariah Watampone dianggap memiliki peran dalam mengembangkan usaha para pedagang kaki lima (PKL) yang mengambil pembiayaan mikro di Pegadaian Syariah terutama dalam masalah permodalan agar dapat lebih meningkatkan potensi dalam bidang usaha yang dijalankan para pedagang kakilima (PKL).

Sebagai lembaga bisnis yang memiliki nilai syariah tentunya pegadaian syariah berbeda dengan pegadaian konvensional. Pegadaian syariah harus akomodatif dengan berbagai persoalan yang berhubungan dengan ekonomi masyarakat. Misalnya dalam masalah jaminan, perlu upaya untuk menerima jaminan yang berhubungan dengan kekayaan hidup masyarakat kecil, seperti hewan ternak (domba, kerbau, sapi atau kuda) atau yang lainnya, yang sering diabaikan pegadaian konvensional. Adapun usaha-usaha yang perlu dilakukan untuk mengembangkan pegadaian syariah antara lain: 
1. Usaha untuk membentuk lembaga pegadaian syariah terus dilakukan sebagai usaha untuk mensosialisasikan praktek ekonomi syariah di masyarakat menengah ke bawah yang mengalami kesulitan dalam mendapatkan pendanaan. Maka perlu kerjasama dari berbagai pihak untuk menentukan langlah-langkah dalam pembentukan lembaga pegadaian syariah yang lebih baik.

2. Masyarakat akan lebih memilih pegadaian disbanding bank disaat mereka membutuhkan dana karena prosedur untuk mendapatkan dana relative lebih mudah disbanding dengan meminjam dana langsung ke bank. Maka cukup alasan bagi pegadaian syariah untuk eksis di tengah-tengah masyarakat yang membutuhkan bantuan.

3. Pegadaian syariah bukan sebagai pesaing yang mengakibatkan kerugian bagi lembaga keuangan syariah lainnya, dan bukan menjadi alasan untuk menghambat berdirinya pegadaian syariah. Dengan keberadaan pegadaian syariah malah akan menambah pilihan bagi masyarakat untuk mendapatkan dana dengan mudah, selain itu hal ini akan meningkatkan tersosialisasikannya keberadaan lembaga keuangan syariah.

4. Pemerintah perlu untuk mengakomodir keberadaan pegadaian syariah ini dengan membuat peraturan pemerintah (PP) atau Undang-Undang (UU) pegadaian syariah. Atau memberikan alternatif keberadaan biro pegadaian syariah dalam Perum Pegadaian Syariah.

Pada tahun 2013 pegadaian menjadi "champion" dalam pembiayaan mikro dan kecil berbasis gadai syariah dan fiducia bagi masyarakat menengah ke bawah, membantu program pemerintah meningkatkan kesejahteraan rakyat khususnya golongan menengah ke bawah dengan memberikan solusi keuangan yang terbaik melalui penyaluran pinjaman skala mikro, kecil dan menengah atas dasar hukum gadai dan fidusia. Memberikan manfaat kepada pemangku kepentingan dan melaksanakan tata kelola perusahaan yang baik secara konsisten. Melaksanakan usaha lain dalam rangka optimalisasi sumber daya. 
Misi Pegadaian sebagai suatu lembaga yang ikut meningkatkan perekonomian dengan cara memberikan uang pinjaman berdasarkan hukum gadai kepada masyarakat kecil, agar terhindar dari praktek pinjaman uang dengan bunga yang tidak wajar ditegaskan dalam keputusan Menteri Keuangan No. Kep-39/MK/6/1/1971 tanggal 20 Januari 1970 dengan tugas pokok sebagai berikut:

1. Membina perekonomian rakyat kecil dengan menyalurkan kredit atas dasar hukum gadai kepada

2. Para petani, nelayan, pedagang kecil, industri kecil, yang bersifat produktif Kaum buruh / pegawai negeri yang ekonomi lemah dan bersifat konsumtif

3. Ikut serta mencegah adanya pemberian pinjaman yang tidak wajar, ijon, pegadaian gelap, dan praktek riba lainnya.

4. Disamping menyalurkan kredit, maupun usaha-usaha lainnya yang bermanfaat terutama bagi pemerintah dan mayarakat

5. Membina pola perkreditan supaya benar-benar terarah dan bermanfaat dan bila perlu memperluas daerah operasinya.

Ketika saya mewawancarai pak agus, mengapa memilih mengambil pembiayaan kreasi di pegadaian? Menurutnya pegadaian memiliki kelebihan di bandingkan dengan lembaga keuangan lainnya karena prosedurnya sederhana, persyaratan ringan dan mudah, tidak perlu membuka seperti tabungan, deposito ataupun giro, Angsuran ringan karena tidak ditentukan besarnya, sehingga dapat diangsur sesuai dengan kemampun. Barang apa yang bapak jaminkan dan berapa dana yang di ambil? Jawabnya yakni BPKB Motor Yamaha di angsur selama 24 bulan dengan pengambilan dana sebesar RP.5.000.000. ketika saya menanyakan mengenai seberapa besar peran pembiayaan pegadaian dalam usaha bapak ? Lalu bapak banyak hanya tersenyum dan kemudian mengatakan sangat berperan karena tanpa ada dana dari pegadaian maka saya juga tidak akan berjualan sebab dana itu saya pakai sebagai modal awal usaha.

Ketika saya mewawancarai pak widodo, mengapa memilih mengambil pembiayaan kreasi di pegadaian? Menurutnya prosedurnya sederhana, hanya 2 hari dana cair, persyaratannya mudah, memperoleh tenggang waktu pelunasan 2 minggu 
setelah jatuh tempo tanpa dibebani bunga, barang yang di jaminkan aman dan terperrcaya. Barang apa yang bapak jaminkan dan berapa dana yang di ambil? Jawabnya yakni BPKB Mobil Avanza di angsur selama 36 bulan dengan pengambilan dana sebesar RP.15.000.000. ketika saya menanyakan mengenai seberapa besar peran pembiayaan pegadaian dalam usaha bapak ? Lalu bapak dengan lantangnya iya karena modal yang di pinjam di gunakan untuk menambah barang campuran karena sebelum peminjaman barang bapak sangat minim terus terkadang permintaan konsumen tidak bisa di sediakan, akan tetapi selama bapak pinjam sudah sanggup menyediakan barang sesuai permintaan pembeli dan pendapatan juga meningkat.

Ketika saya mewawancarai ibu muliati, mengapa memilih mengambil pembiayaan kreasi di pegadaian? Menurutnya prosedurnya sederhana, barang yang di jaminkan hanya bpkb, aman, murah dan terpercaya. Barang apa yang bapak jaminkan dan berapa dana yang di ambil? Jawabnya yakni BPKB Motor di angsur selama 18 bulan dengan pengambilan dana sebesar RP.3.500.000. ketika saya menanyakan mengenai seberapa besar peran pembiayaan pegadaian dalam usaha ibu ? jawabnya iya karena modal pinjaman saya gunakan sebagai modal awal dan dengan adanya modal ini maka saya berprofesi sebagai penjual sebab sebelum ada dana saya hanya tinggal di rumah saja menjadi ibu rumah tangga.

\section{B. Deskripsi kesyariahaan kreasi bagi pedagang kaki lima di Watampone}

Islam datang dengan serangkaian pemahaman tentang kehidupan yang membentuk pandangan hidup tertentu. Islam hadir dalam bentuk garis-garis hukum yang global, yakni makna-makna tekstual yang umum, yang mampu memecahkan seluruh problematika kehidupan manusia baik yang meliputi aspek ritual maupun social. Dengan demikian akan dapat digali berbagai cara pemecahan setiap masalah yang timbul dalam kehidupan manusia.

Dalam menjawab permasalahan yang timbul nampaknya peranan hukum islam dalam konteks kekinian dan kemoderenan dewasa ini sangat diperlukan dan tidak dapat lagi untuk dihindarkan. Agama islam juga mengajarkan kepada umatnya supaya hidup saling tolong menolong, yang kaya harus menolong yang miskin yang mampu 
harus menolong yang tidak mampu. Bentuk tolong-menolong ini bisa dalam bentuk pemberian dan bisa berupa pinjaman.

Dalam bentuk pinjaman hukum islam menjaga kepentingan kreditur, jangan sampai ia dirugikan. Oleh sebab itu ia dibolehkan meminta barang dari debitur sebagai jaminan utangnya. Sehingga apabila debitur itu tidak mampu melunasi pinjamannya, maka barang jaminan boleh dijual oleh kreditur. Konsep tersebut dalam islam dikenal dengan istilah rahn atau gadai.

Gadai merupakan salah satu kategori dari perjanjian utang-piutang yang mana untuk suatu kepercayaan dari orang yang berpiutang, maka orang yang berutang menggadaikan barangnya sebagai jaminan terhadap utangnya itu. Barang jaminan tetap milik orang yang menggadaikan (orang yang berutang) tetapi dikuasai oleh penerima gadai (yang berpiutang). Praktek seperti ini sudah ada sejak jaman rasulullah SAW. Dan rasulullah sendiri penah melakukannya. Gadai memiliki nilai sosial yang sangat tinggi dan dilakukan secara sukarela atas dasar tolong-menolong.

\section{Dari Abu Hurairah r.a., Nabi S.A.W. bersabda:}

"Tidak terlepas kepemilikan barang gadai dari pemilik yang menggadaikannya. la memperoleh manfaat dan menanggung resikonya".(HR. Asya-Syafi'l, Al-Daruquthni dan Ibnu Majah)

\section{Nabi S.A.W. bersabda :}

"Tunggangan (kendaraan) yang digadaikan boleh dinaiki dengan menanggung biayanya dan binatang ternak yang digadaikan dapat diperah susunya dengan menanggung biayanya. Bagi yang menggunakan kendaraan dan memerah susu wajib menyediakan biaya perawatan dan pemeliharaan". (HR. Jamaah kecuali Muslim , Nasa'l dan Bukhari)

\section{Fatwa DSN}


Landasan ini kemudian diperkuat dengan Fatwa Dewan Syariah Nasional no 25/DSN-MUI/III/2002 tanggal 26 Juni 2002 yang menyatakan bahwa pinjaman dengan menggadaikan barang sebagai jaminan utang dalam bentuk rahn diperbolehkan dengan ketentuan sebagai berikut :

- Ketentuan Umum :

1. Murtahin (penerima barang) mempunya hak untuk menahan Marhun (barang) sampai semua utang rahin (yang menyerahkan barang) dilunasi.

2. Marhun dan manfaatnya tetap menjadi milik Rahin. Pada prinsipnya marhun tidak boleh dimanfaatkan oleh murtahin kecuali seizin Rahin, dengan tidak mengurangi nilai marhun dan pemanfaatannya itu sekedar pengganti biaya pemeliharaan perawatannya.

3. Pemeliharaan dan penyimpanan marhun pada dasarnya menjadi kewajiban rahin, namun dapat dilakukan juga oleh murtahin, sedangkan biaya dan pemeliharaan penyimpanan tetap menjadi kewajiban rahin.

4. Besar biaya administrasi dan penyimpanan marhun tidak boleh ditentukan berdasarkan jumlah pinjaman.

5. Penjualan marhun

- Ketentuan Penutup

1. Jika salah satu pihak tidak dapat menunaikan kewajibannya atau jika terjadi perselisihan diantara kedua belah pihak, maka penyelesaiannya dilakukan melalui Badan Arbritase Syariah setelah tidak tercapai kesepakatan melalui musyawarah.

2. Fatwa ini berlaku sejak tanggal ditetapkan dengan ketentuan jika di kemudian hari terdapat kekeliruan akan diubah dan disempurnakan sebagai mana mestinya.

\section{KESIMPULAN DAN SARAN}

\section{Kesimpulan}


Berdasarkan hasil penelitian dan pembahasan diatas, maka dapat ditarik kesimpulan bahwa:

2. Kreasi adalah kredit dengan angsuran bulanan yang diberikan kepada usaha kecil dan menengah (UKM) untuk pengembangan usaha dengan sistem fidusia.Sistem fidusia berarti agunan untuk pinjaman cukup dengan BPKB sehingga kendaraan masih digunakan nasabah. Kreasi merupakan solusi terpercaya untuk mendapatkan fasilitas kredit yang cepat,mudah dan murah.

3. Peran aktual pegadaian dalam pengembangan usaha pedagang kaki lima di Watampone sangat berperan karena dapat meningkatkan usaha pedagang, membantu masyarakat untuk membuka usaha dan juga membantu meningkatkan pendapatan pedagang kaki lima.

\section{Saran}

Berdasarkan hasil penelitian penulis maka dapat disarankan sebagai berikut:

Berdasarkan kesimpulan di atas, maka penulis memberikan saran kepada pedagang kaki lima agar merealisasikan dengan baik dana yang di berikan oleh pegadaian dalam kegiatan perusahaannya karena dapat mendatangkan lat bagi pedagang kaki lima dan dalam tinjauan ekonomi Islam apabila dana digu dengan baik maka akan mendatangkan manfaat yang besar bagi negara.

\section{DAFTAR RUJUKAN}

Achsan, Ali Mustafa, Transformasi Sosial Masyarakat Marginal' Malang: INSPIRE, 2008.

Bromly Ray, Organisasi, Peraturan dan Pengusahaan Sektor Informal Di Kota dalam Urbanisasi, Pengangguran dan Sektor Informal di Kota, Chris Manning, Tajudin Noer Efendi, Jakarta, Yayasan Obor Indonesia, 2007.

Badan Pusat Statistik Kabupaten Bone, Statistik Daerah Kabupaten Bone Tahun 2016, Kabupaten Bone: BPS Kabupaten Bone, 2016.

Badan Pusat Statistik Kabupaten Bone, Statistik Daerah Kabupaten Bone Tahun 2016.

D.A. Aaker, dkk, Marketing Research Hawkin: Mac. Millan Publishing Company, 2001. 
Fitriani, "Pengaruh Minat Pedagang Kaki Lima Terhadap Pengambilan Kredit Pada Koperasi Mattiro Deceng Di Watampone" Hasil Penelitian Individual Mahasiswi, Sekolah Tinggi Agama Islam Negeri (STAIN) Watampone, 2014, h.

Hartati Sugi, Sukses Memiliki Usaha Kuliner Tanpa Modal, Jakarta:Cetakan I,2014.

Indonesia, Universitas Islam. Al Qur'an dan Tafsirnya Jilid I Juz 1-2-3. Yogyakarta : PT. Verisia Yogya Grafika.1999.

Karim, Adiwarman A' Bank Islam Analisis Fiqh dan Keuangan, Jakarta: PT Raja Grafindo Persada, 2001.

Moleong, Lexy J, Metodologi Penelitian Kualitatif, Bandung: PT Remaja Rosdakarya, 2004.

Muhammad, Analisis Kekuatan, Peluang, Kelemahan dan Ancaman, Yogyakarta: Ekonisia, 2006.

Muhammad, Teknik Perhitungan Bagi Hasil dan Profit Margin Bank Syariah, UII Press, Yogyakarta, 2006, h. 7.

Mungim Burhan, Peneltian Kualitatif: Komunikasi, Ekonomi, Kebijakan Publik, Dan IImu Sosial Lainnya, Jakarta: Prenada Media Group, 2008.

Nasution S, Metodologi Research Penelitian Ilmiah Jakarta: Bumi Aksara, 2000.

Supardi, Metodologi Penelitian Ekonomi \& Bisnis, Yogyakarta: UII Press, 2005.

Syahruddin Kadir, "Pembiayaan Modal Kerja Lembaga Keuangan Mikro Syariah Analisis Profitabilitas BMT As'adiyah Sengkang" Hasil Penelitian Individual Mahasiswa, Sekolah Tinggi Agama Islam Negeri (STAIN) Watampone, 2014.

Teguh, Muhammad, Metodologi Penelitian Ekonomi: Teori dan Aplikasi, Jakarta: RajaGrafindo Persada, 2005.

Tim Pengembangan Perbankan Syariah Institut Bankir Indonesia.

Tim Penyusun Kamus Pusat Bahasa, Kamus Besar Bahasa Indonesia, Jakarta : Balai Pustaka, 2002. 